\title{
Treadmill exercise alleviates impairment of cognitive function by enhancing hippocampal neuroplasticity in the high-fat diet-induced obese mice
}

\author{
Tae-Woon Kim'1, Hyun-Hee Choi², Yong-Rak Chung ${ }^{3, *}$ \\ 1Department of Physiology, College of Medicine, Kyung Hee University, Seoul, Korea \\ ${ }^{2}$ Division of Leisure \& Sports Science, Department of Exercise Prescription, Dongseo University, Busan, Korea \\ ${ }^{3}$ Department of Golf Mapping, College of Arts Physical Education, Joongbu University, Geumsan, Korea
}

Physical exercise is one of the most effective methods for managing obesity, and exercise exerts positive effects on various brain functions. Excessive weight gain is known to be related to the impairment of cognitive function. High-fat diet-induced obesity impairs hippocampal neuroplasticity, which impedes cognitive function, such as learning ability and memory function. In this study, we investigated the effect of treadmill exercise on impairment of cognitive function in relation with hippocampal neuroplasticity using high-fat diet-induced obese mice. After obesity was induced by a 20 -week high-fat $(60 \%)$ diet, treadmill exercise was performed for 12 weeks. In the present results, cognitive function was impaired in the high-fat diet-induced obese mice. Brain-de- rived neurotrophic factor (BDNF) and tyrosin kinase B (TrkB) expression and cell proliferation were decreased in the high-fat diet-induced obese mice. Treadmill exercise improved cognitive function through enhancing neuroplasticity, including increased expression of BDNF and TrkB and enhanced cell proliferation. The present results suggest that treadmill exercise enhances hippocampal neuroplasticity, and then potentially plays a protective role against obesity-induced cognitive impairment.

Keywords: Treadmill exercise, High-fat diet, Obesity, Hippocampus, Neuroplasticity

\section{INTRODUCTION}

Increased body mass index (BMI) raises the risk for Alzheimer's disease, and this increment of BMI is associated with brain atrophy (Gustafson et al., 2003; Gustafson et al., 2004). Many studies reported that excess weight gain is associated with reduced cognitive function (Gunstad et al., 2006; Jeong et al., 2005). High-fat diet is closely related to deterioration of hippocampal neuroplasticity, neuronal degenerative diseases, and impairment of cognitive function (Molteni et al., 2002; Stranahan et al., 2008). Obesity is known to induce deterioration of cognitive function disorders, regardless of age (Jurdak et al., 2008; Winocur and Greenwood, 2005).

High-fat diet impairs hippocampal structure and functions
(Molteni et al., 2002), and such impairment is associated with deterioration of hippocampal synaptic plasticity and suppression of neurogenesis (Farr et al., 2008; Lindqvist et al., 2006; Molteni et al., 2002; Park et al., 2010). For the detection of newly formed neurons, 5-bromo-2'-deoxyridine (BrdU) immunohistochemistry has widely been used. Decrement of these numbers represents suppression of new cell formation (Kim et al., 2013; Kim et al., 2015; Lee et al., 2015).

The developmental stages of neurogenesis are characterized by stage-specific markers, such as doublecortin (DCX) (Ming and Song, 2005). DCX is a marker of neuronal precursor cells, and DCX expression is associated with neuronal plasticity in the adult mammals (Friocourt et al., 2007; von Bohlen und Halbach, 2011). Cell proliferation and DCX expression in the hippocampus
${ }^{*}$ Corresponding author: Yong-Rak Chung (D) http://orcid.org/0000-0002-1458-5260 Department of Golf Mapping, College of Arts Physical Education, Joongbu University, 201 Daehak-ro, Chubu-myeon, Geumsan 32713, Korea Tel: +82-41-750-6585, Fax: +82-41-750-6587, E-mail: yrjung@joongbu.ac.kr Received: May 1, 2016 / Accepted: May 30, 2016
This is an Open Access article distributed under the terms of the Creative Commons Attribution Non-Commercial License (http://creativecommons.org/licenses/by-nc/4.0/) which permits unrestricted non-commercial use, distribution, and reproduction in any medium, provided the original work is properly cited. 
also showed positive correlation with memory function (Kim and Seo, 2013).

Neurotrophic factors are critical in regulating the generation, differentiation, and proliferation of neurons, and in maintaining neuronal plasticity. Of these, brain-derived neurotrophic factor (BDNF) is a small dimeric protein and works through high affinity binding with its receptor, tyrosin kinase $\mathrm{B}$ (TrkB). BDNF is also implicated in the pathophysiology of several brain injury patients (Ke and Zhang, 2013; Simon et al., 2016). Reduction of BDNF level in the hippocampus impairs learning and memory performance in animals (Kim et al., 2013; Sairanen et al., 2005). Also, BDNF regulate obesity and central energy balance (Park et al., 2010).

Exercise has a positive effect on various brain disorders, including depression, Alzheimer disease, and Parkinson disease (Blumenthal et al., 2007; Hirsch et al., 2003; Rolland et al., 2007). Exercise promotes hippocampal neurogenesis and BDNF expression, enhances neuronal plasticity, induces positive changes in DNA transcription involved in neuronal activity and regeneration, and enhances the activity of brain mitochondria (Itoh et al. 2011; Kim et al., 2015; Navarro et al., 2004). Thus, in this study, we evaluated the hypothesis that exercise may reverse impaired cognitive function induced by high fat intake during 20 weeks.

\section{MATERIALS AND METHODS}

\section{Animals and housing conditions}

All animal experimental procedures conformed to the regulations stipulated by the National Institutes of Health and the guidelines of the Korean Academy of Medical Science. This study was approved by the Kyung Hee University Institutional Animal Care and Use Committee (KHUASP [SE]-14-018) (Seoul, Korea). The mice were housed under controlled temperature $\left(20^{\circ} \mathrm{C} \pm 2^{\circ} \mathrm{C}\right)$ and lighting (07:00 a.m. to 19:00 p.m.) conditions with food and water available ad libitum. Male C57BL/6 mice (4 weeks old) were randomly divided into 4 groups ( $\mathrm{n}=10$ per group): control group $(\mathrm{CON})$, control and exercise group $(\mathrm{CON}+\mathrm{EX})$, high-fat diet group (HFD), and high-fat diet and exercise group (HFD+EX). The high-fat diet containing fat $60 \%$ was freely provided. All rats received 50-mg/kg BrdU (Sigma Chemical Co., St. Louis, MO, USA) intraperitoneally once a day for 3 consecutive days, starting the experiment.

\section{Exercise protocol}

Exercise protocol was listed in the Table 1.
Table 1. Treadmill exercise started 20 weeks after the intake of high fat diet

\begin{tabular}{lcccc}
\hline Exercise period (wk) & $\begin{array}{c}\text { Warm-up } \\
(\mathrm{m} / \mathrm{min})\end{array}$ & $\begin{array}{c}\text { Exercise } \\
(\mathrm{m} / \mathrm{min})\end{array}$ & $\begin{array}{c}\text { Cool-down } \\
(\mathrm{m} / \mathrm{min})\end{array}$ & $\begin{array}{c}\text { Time } \\
(\mathrm{min})\end{array}$ \\
\hline $0-2$ & & 10 & & 30 \\
$3-4$ & & 10 & & 40 \\
$5-6$ & 5 & 13 & 5 & 30 \\
$7-8$ & & 13 & & 40 \\
$9-10$ & & 16 & & 40 \\
$11-12$ & & 16 & & 50 \\
\hline
\end{tabular}

\section{Behavior test}

In order to evaluate the short-term memory and spatial memory ability, Y-maze test and radial-8-arm maze test were performed, according to the previously describe method (Kim et al., 2011; Kim et al., 2015; Kim and Seo, 2013). The Y-maze used in the present study consisted of three arms (length, $35 \mathrm{~cm}$; height, 25 $\mathrm{cm}$; and width, $10 \mathrm{~cm}$ ) and an equilateral triangular central area. The mice were placed at the end of one arm and allowed to move freely through the maze for $8 \mathrm{~min}$. The radial-8-arm maze in the present study consisted of a central octagonal plate (diameter, 30 $\mathrm{cm}$ ) and 8 radiating arms (length, $50 \mathrm{~cm}$; width, $10 \mathrm{~cm}$ ). A small receptacle filled with water (dimeter, $3 \mathrm{~cm}$; depth, $1 \mathrm{~cm}$ ) was located at the end of the arms. The mice were trained before the spatial learning test. The mice were deprived of water $24 \mathrm{hr}$ and were allowed to explore the water. The time spent in seeking water at the end of the arms was counted. The test was terminated when a mouse found water in all 8 arms or when $>8$ min elapsed. Re-entry into the previously visited arms was counted as an error. In addition, the number of correct choice before the first error was counted.

\section{Tissue preparation}

The animals were sacrificed immediately after determination of radial-8-arm maze test. To prepare the brain slices, the animals were fully anesthetized with diethyl ether after which the mice were transcardially perfused with 50-mM phosphate-buffered saline (PBS) and then fixed with freshly prepared solution of $4 \%$ paraformaldehyde in 100-mM phosphate buffer $(\mathrm{pH}, 7.4)$. The brains were then removed, postfixed in the same fixative overnight, and transferred into a $30 \%$ sucrose solution for cryoprotection. Coronal sections with thicknesses of $40 \mu \mathrm{m}$ were made using a freezing microtome (Leica, Nussloch, Germany).

\section{Western blot for BDNF and TrkB}

BDNF and TrkB expression in the hippocampus was deter- 
mined by western blot analysis, according to the previously described method (Kim et al., 2013; Kim et al., 2015). The hippocampus tissues were homogenized on ice and lysed in a lysis buffer containing 50-mM Tris- $\mathrm{HCl}(\mathrm{pH}, 7.5), 150-\mathrm{mM} \mathrm{NaCl}, 0.5 \%$ deoxycholic acid, $1 \%$ Nonidet $\mathrm{P} 40,0.1 \%$ sodium dodecyl sulfate (SDS), 1-mM phenylmethanesulfonyl fluoride, and $100-\mathrm{mg} / \mathrm{mL}$ leupeptin. Protein content was measured using a Bio-Rad colorimetric protein assay kit (Bio-Rad, Hercules, CA, USA). Protein of $30 \mu \mathrm{g}$ was separated on SDS-polyacrylamide gels and transferred onto a nitrocellulose membrane, which was incubated with mouse $\beta$-actin antibody (1:1,000; Santa Cruz Biotechnology, Santa Cruz, CA, USA), rabbit BDNF and TrkB antibody (1:1,000; Santa Cruz Biotechnology). Horseradish peroxidase-conjugated antirabbit antibody for BDNF and TrkB, and antirabbit for $\beta$-actin were used as secondary antibodies.

\section{Immunohistochemistry for BrdU}

To detect newly generated cells in the dentate gyrus, BrdU-specific immunohistochemistry was performed, according to the previously described method (Lee et al., 2015; Kim et al., 2015). The sections were first permeabilized by incubation in $0.5 \%$ Triton $\mathrm{X}-100$ in PBS for $20 \mathrm{~min}$, then pretreated in 50\% formamide-2 $\times$ standard saline citrate at $65^{\circ} \mathrm{C}$ for $2 \mathrm{hr}$, denatured in $2 \mathrm{~N} \mathrm{HCl}$ at $37^{\circ} \mathrm{C}$ for $30 \mathrm{~min}$, and rinsed twice in $100-\mathrm{mM}$ sodium borate $(\mathrm{pH}$, 8.5). Afterwards, the sections were incubated overnight at $4{ }^{\circ} \mathrm{C}$ with BrdU-specific mouse monoclonal antibody (1:600; Roche, Mannheim, Germany). The sections were then washed three times with PBS and incubated with biotinylated mouse secondary antibody (1:200; Vector Laboratories, Burlingame, CA, USA) for $1 \mathrm{hr}$. The sections were then incubated for another $1 \mathrm{hr}$ with an avidin-peroxidase complex (1:100; Vector Laboratories). For visualization, sections were incubated in $50-\mathrm{mM}$ Tris- $\mathrm{HCl}(\mathrm{pH}, 7.6)$ containing $0.03 \%$ diaminobenzidine (DAB), $40-\mathrm{mg} / \mathrm{mL}$ nickel chloride, and $0.03 \%$ hydrogen peroxide for $5 \mathrm{~min}$.

After BrdU staining, the differentiation of BrdU-positive cells was determined on the same section using a mouse antineuronal nucleic antibody (1:1,000; Chemicon International, Temecula, CA, USA). The sections were washed 3 times with PBS, incubated for $1 \mathrm{hr}$ with a biotinylated antimouse secondary antibody. For staining, the sections were incubated in a reaction mixture consisting of $0.03 \% \mathrm{DAB}$ and $0.03 \%$ hydrogen peroxide for $5 \mathrm{~min}$. The sections were mounted onto gelatin-coated slides, air-dried overnight at room temperature, and coverslips were mounted using Permount (Fisher Scientific, New Jersey, NJ, USA).

\section{Immunohistochemistry for DCX}

To visualize DCX expression, immunohistochemistry for DCX in the hippocampus was performed, according to the previously described method (Kim et al., 2014; Kim and Seo, 2013). The sections were incubated in PBS for $10 \mathrm{~min}$, and then washed three times in the same buffer. The sections were then incubated in $1 \%$ hydrogen peroxide for $30 \mathrm{~min}$. The sections were selected from each brain and incubated overnight with goat anti-DCX antibody (1:1,000; Oncogene Research Product, Cambridge, UK) and then with biotinylated rabbit secondary antibody (1:200; Vector Laboratories) for another $1 \mathrm{hr}$. The secondary antibody was amplified with the Vector Elite ABC kit (1:100; Vector Laboratories). Antibody-biotin-avidin-peroxidase complexes were visualized using $0.03 \% \mathrm{DAB}$, and the sections were mounted onto gelatin-coated slides. The slides were air-dried overnight at room temperature, and the coverslips were mounted using Permount (Fisher Scientific).

\section{Statistical analysis}

For confirming the expression of BDNF and TrkB, the detected bands were calculated densitometrically using Molecular Analyst, ver. 1.4.1 (Bio-Rad). The number of BrdU-positive and DCXpositive cells in the dentate gyrus was counted hemilaterally under a light microscope (Olympus, Tokyo, Japan), and they were expressed as the numbers of cells per square millimeter in the dentate gyrus. The area of the dentate gyrus was measured by Image-Pro Plus image analysis system (Media Cyberbetics Inc., Silver Spring, MD, USA). The data were analyzed with one-way analysis of variance and then Duncan post hoc tests. All values are expressed as the mean \pm standard error of the mean, and $P$-value of $<0.05$ was considered significant.

\section{RESULTS}

\section{Effect of treadmill exercise on short-term and spatial memory}

The percentage of the spontaneous alteration in the Y-maze test was lower in the high-fat diet-induced obese mice than control mice (Fig. 1A). In the radial-8-arm maze test, the correct number was lower (Fig. 1B) and the error number was higher (Fig. 1C) in the high-fat diet-induced obese mice than control mice. The present results indicated that short-term and spatial memory was deteriorated by high-fat diet-induced obesity $(P<0.05)$. However, treadmill exercise alleviated the deterioration of short-term and spatial memory in the high-fat diet-induced obese mice. 

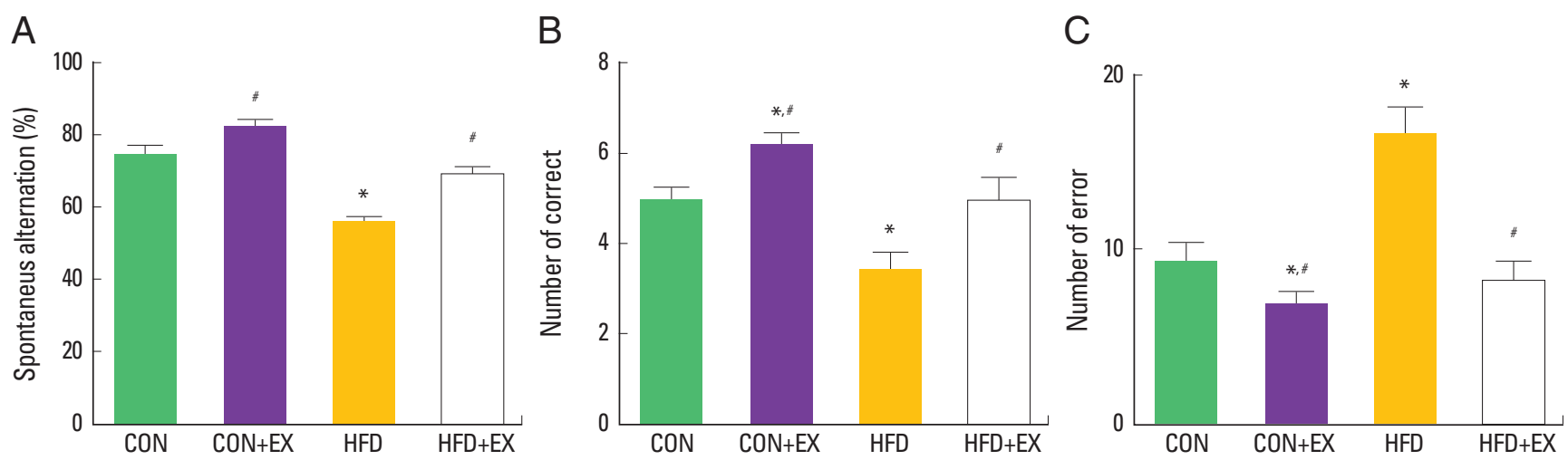

Fig. 1. Effect of treadmill exercise on short-term and spatial memory. (A) Short-term memory in Y-maze task, (B) correct number in the radial-8-arm maze test, and (C) error number in the radial-8-arm maze test. CON, control group; CON+EX, control and exercise group; HFD, high-fat diet group; HFD+EX, high-fat diet and exercise group. Data are expressed as the mean \pm standard error of the mean. ${ }^{*} P<0.05$ compared to the CON group. ${ }^{\sharp} P<0.05$ compared to the HFD group.

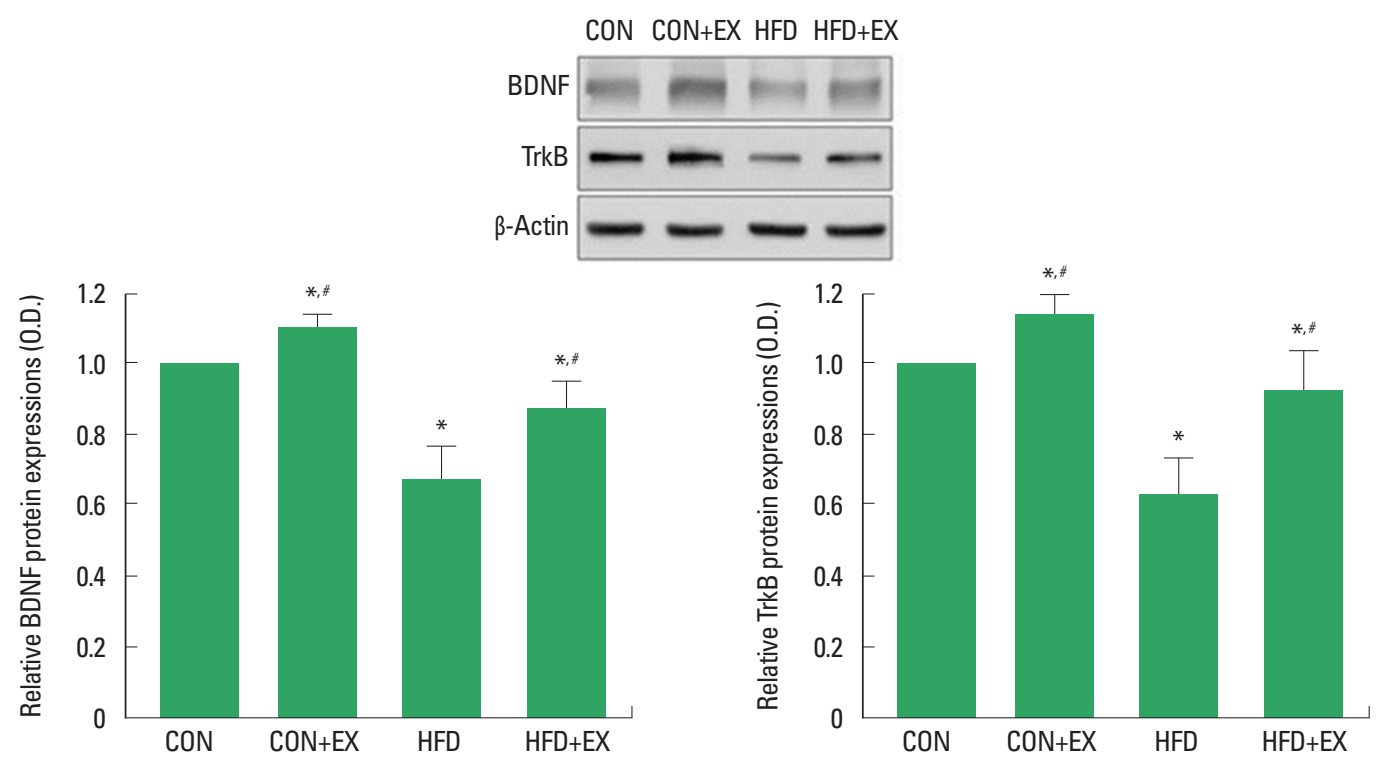

Fig. 2. Effect of treadmill exercise on brain-derived neurotrophic factor (BDNF) and tyrosin kinase B (TrkB) in hippocampus. CON, control group; CON+EX, control and exercise group; HFD, high-fat diet group; $H F D+E X$, high-fat diet and exercise group. Data are expressed as the mean \pm standard error of the mean. ${ }^{*} P<0.05$ compared to the CON group. ${ }^{*} P<0.05$ compared to the HFD group.

\section{Effect of treadmill exercise on BDNF and TrkB expression in the hippocampus}

The expression of BDNF and TrkB in the hippocampus was analyzed (Fig. 2). The present results showed that high-fat diet-induced obesity decreased the expression of BDNF and TrkB $(P<0.05)$. However, treadmill exercise increased BDNF and TrkB expression in the high-fat diet-induced obese mice $(P<0.05)$.

\section{Effect of treadmill exercise on cell differentiation in hippocampal dentate gyrus}

Cell differentiation in hippocampal dentate gyrus was analyzed by DCX-positive cells (Fig. 3). The present results demonstrated that the number of DCX-positive cells was decreased by high-fat diet-induced obesity $(P<0.05)$. However, treadmill exercise increased the number of DCX-positive cells in the high-fat diet-induced obese mice $(P<0.05)$.

\section{Effect of treadmill exercise on cell proliferation in hippocampal dentate gyrus}

Cell proliferation in hippocampal dentate gyrus was analyzed by BrdU-positive cells (Fig. 4). The present results demonstrated that the number of BrdU-positive cells was decreased by high-fat 

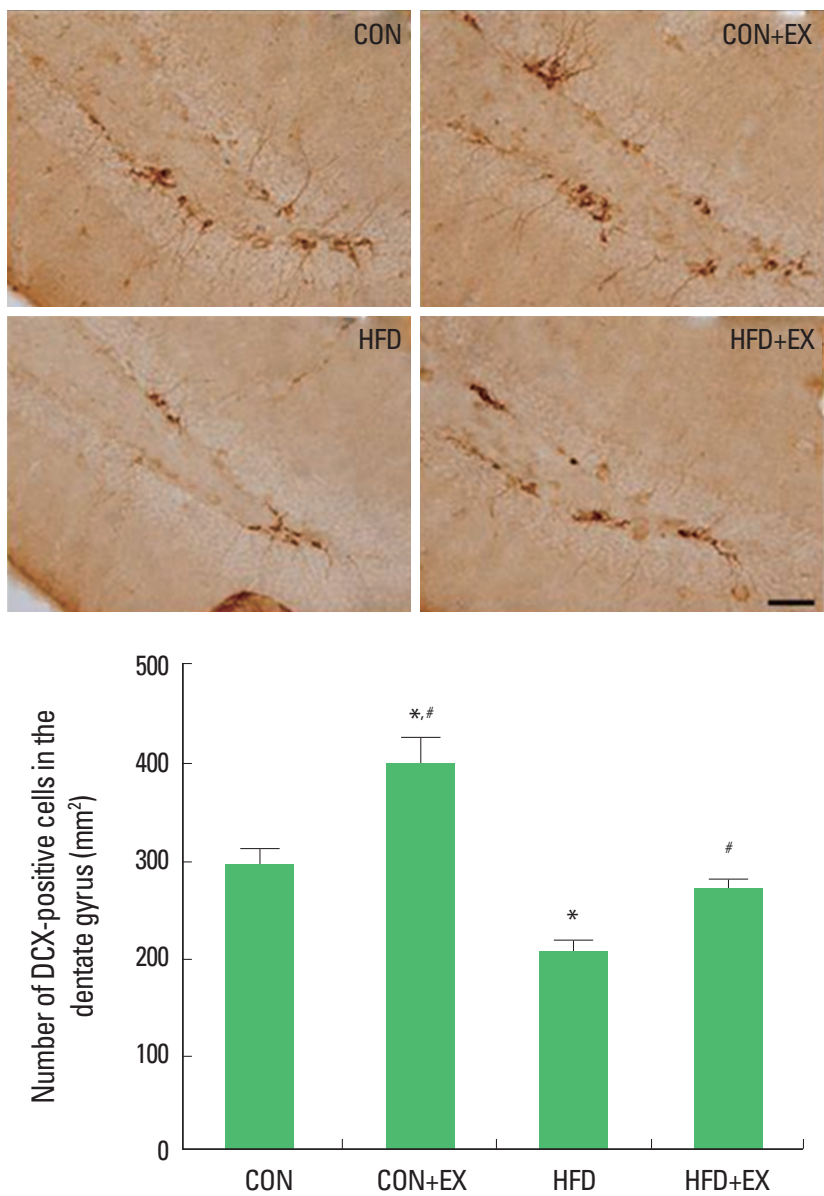

Fig. 3. Effect of treadmill exercise on cell differentiation in the hippocampal dentate gyrus. Upper panel: Photomicrographs of doublecortin (DCX)-positive cells (immunohistochemistry). The scale bar represents $50 \mu \mathrm{m}$. Lower panel: The number of DCX-positive cells in each group. CON, control group; CON+EX control and exercise group; HFD, high-fat diet group; HFD+EX, high-fat diet and exercise group. Data are expressed as the mean \pm standard error of the mean. ${ }^{*} P<0.05$ compared to the CON group. ${ }^{\#} P<0.05$ compared to the HFD group.

diet-induced obesity $(P<0.05)$. However, treadmill exercise increased the number of BrdU-positive cells in the high-fat diet-induced obese mice $(P<0.05)$.

\section{DISCUSSION}

In the present study, short-term and spatial memory was decreased by high-fat diet for 32 weeks. The previous study suggested that high-fat diet deteriorated hippocampus-dependent spatial learning ability before the occurring the metabolic disorders, such as hypercholesterolemia and hyperinsulinemia (Valladolid-Acebes et al., 2011). Obesity impaired cognitive function and increased vulnerability to brain damage (Bruce-Keller et al., 2009).
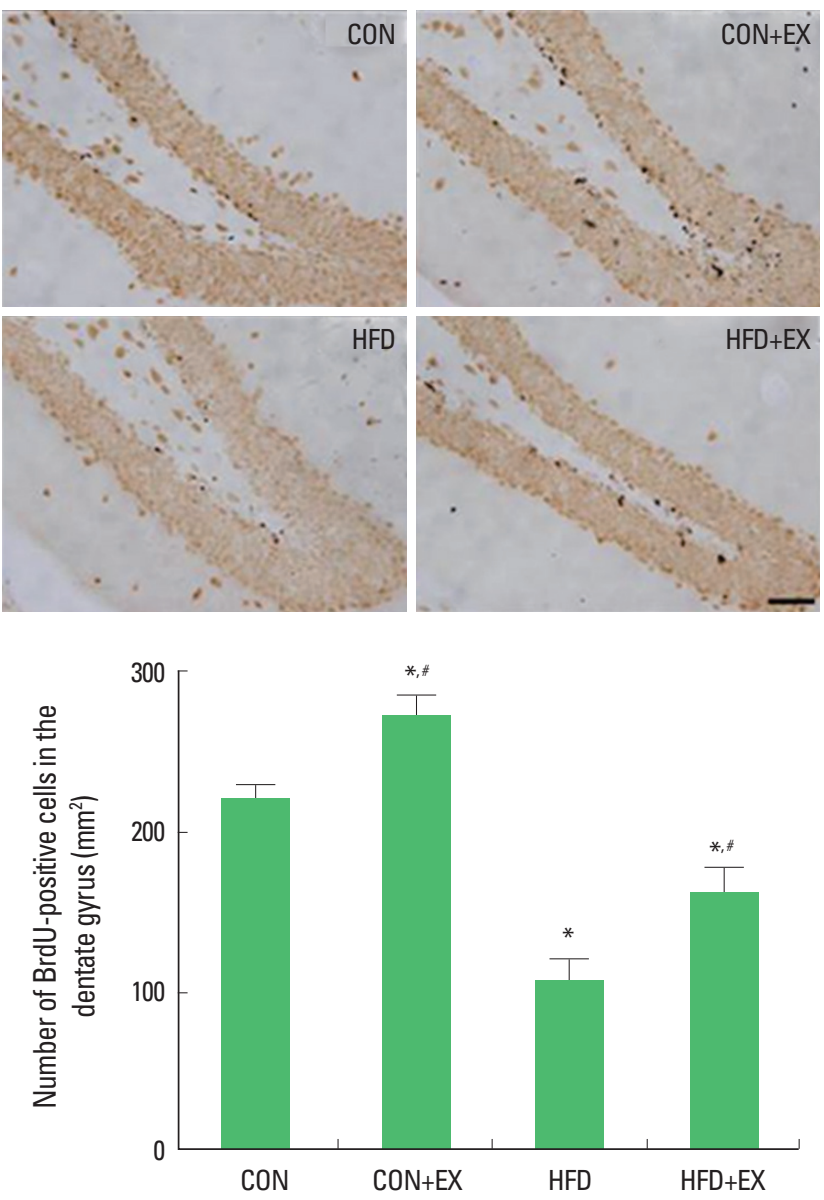

Fig. 4. Effect of treadmill exercise on cell proliferation in the hippocampal dentate gyrus. Upper panel: Photomicrographs of 5-bromo-2'-deoxyridine (BrdU)-positive cells (immunohistochemistry). The scale bar represents $50 \mu \mathrm{m}$. Lower panel: The number of BrdU-positive cells in each group. CON, control group; $\mathrm{CON}+\mathrm{EX}$, control and exercise group; HFD, high-fat diet group; HFD+EX, high-fat diet and exercise group. Data are expressed as the mean \pm standard error of the mean. ${ }^{*} P<0.05$ compared to the $\mathrm{CON}$ group. ${ }^{\sharp} P<0.05$ compared to the HFD group.

In the present study, reduced hippocampal neuroplasticity caused impaired memory function in the high-fat diet-induced obese mice. BDNF and TrkB expression and cell proliferation were decreased in the high-fat diet-induced obese mice. Exercise is one of the most effective methods managing obesity and exercise prevents dementia or impairment of cognitive function. In the present study, treadmill exercise for 12 weeks starting 20 weeks after high-fat diet improved cognitive function, and this improvement of cognitive function was accompanied by increased expression of BDNF and TrkB with enhanced cell proliferation. In animal models of obesity and diabetes, exercise increased hippocampal BDNF expression and enhanced cell proliferation and 
differentiation (Woo et al., 2013; Yi et al., 2009). BDNF is known to regulate energy metabolism by increasing glucose consumption in response to an energy-requiring activity, such as neuronal differentiation (Burkhalter et al., 2003). In the present study, increased expression of hippocampal BDNF and TrkB and enhanced cell proliferation caused by treadmill exercise might facilitate neuroplasticity in the high-fat diet-induced obese mice.

In the high-fat diet-induced obese mice, impaired cognitive function might be ascribed to the decrement in hippocampal neuroplasticity. Treadmill exercise activated hippocampal neuroplasticity, resulting in improvement in cognitive function in the highfat diet-induced obese mice. The present results suggest that treadmill exercise enhances hippocampal neuroplasticity, and then potentially plays a protective role against obesity-induced cognitive impairment.

\section{CONFLICT OF INEREST}

No potential conflict of interest relevant to this article was reported.

\section{ACKNOWLEDGMENTS}

This work was supported by the National Research Foundation of Korea Grant funded by the Korean Government (NRF-2013 S1A5B5A01031478).

\section{REFERENCES}

Blumenthal JA, Babyak MA, Doraiswamy PM, Watkins L, Hoffman BM, Barbour KA, Herman S, Craighead WE, Brosse AL, Waugh R, Hinderliter A, Sherwood A. Exercise and pharmacotherapy in the treatment of major depressive disorder. Psychosom Med 2007;69:587-596.

Bruce-Keller AJ, Keller JN, Morrison CD. Obesity and vulnerability of the CNS. Biochim Biophys Acta 2009;1792:395-400.

Burkhalter J, Fiumelli H, Allaman I, Chatton JY, Martin JL. Brain-derived neurotrophic factor stimulates energy metabolism in developing cortical neurons. J Neurosci 2003;23:8212-8220.

Farr SA, Yamada KA, Butterfield DA, Abdul HM, Xu L, Miller NE, Banks WA, Morley JE. Obesity and hypertriglyceridemia produce cognitive impairment. Endocrinology 2008;149:2628-2636.

Friocourt G, Liu JS, Antypa M, Rakic S, Walsh CA, Parnavelas JG. Both doublecortin and doublecortin-like kinase play a role in cortical interneuron migration. J Neurosci 2007;27:3875-3883.

Gunstad J, Paul RH, Cohen RA, Tate DF, Gordon E. Obesity is associated with memory deficits in young and middle-aged adults. Eat Weight Disord 2006;11:e15-19.

Gustafson D, Lissner L, Bengtsson C, Björkelund C, Skoog I. A 24-year follow-up of body mass index and cerebral atrophy. Neurology 2004;63:1876-1881.

Gustafson D, Rothenberg E, Blennow K, Steen B, Skoog I. An 18-year follow-up of overweight and risk of Alzheimer disease. Arch Intern Med 2003;163:1524-1528.

Hirsch MA, Toole T, Maitland CG, Rider RA. The effects of balance training and high-intensity resistance training on persons with idiopathic Parkinson's disease. Arch Phys Med Rehabil 2003;84:1109-1117.

Itoh T, Imano M, Nishida S, Tsubaki M, Hashimoto S, Ito A, Satou T. Exercise increases neural stem cell proliferation surrounding the area of damage following rat traumatic brain injury. J Neural Transm (Vienna) 2011;118:193-202.

Jeong SK, Nam HS, Son MH, Son EJ, Cho KH. Interactive effect of obesity indexes on cognition. Dement Geriatr Cogn Disord 2005;19:91-96.

Jurdak N, Lichtenstein AH, Kanarek RB. Diet-induced obesity and spatial cognition in young male rats. Nutr Neurosci 2008;11:48-54.

Ke XJ, Zhang JJ. Changes in HIF-1 $\alpha$, VEGF, NGF and BDNF levels in cerebrospinal fluid and their relationship with cognitive impairment in patients with cerebral infarction. J Huazhong Univ Sci Technolog Med Sci 2013;33:433-437.

Kim BK, Seo JH. Treadmill exercise alleviates post-traumatic stress disorder-induced impairment of spatial learning memory in rats. J Exerc Rehabil 2013;9:413-419.

Kim BK, Shin MS, Kim CJ, Baek SB, Ko YC, Kim YP. Treadmill exercise improves short-term memory by enhancing neurogenesis in amyloid beta-induced Alzheimer disease rats. J Exerc Rehabil 2014;10:2-8.

Kim H, Heo HI, Kim DH, Ko IG, Lee SS, Kim SE, Kim BK, Kim TW, Ji ES, Kim JD, Shin MS, Choi YW, Kim CJ. Treadmill exercise and methylphenidate ameliorate symptoms of attention deficit/hyperactivity disorder through enhancing dopamine synthesis and brain-derived neurotrophic factor expression in spontaneous hypertensive rats. Neurosci Lett 2011;504:35-39.

Kim K, Sung YH, Seo JH, Lee SW, Lim BV, Lee CY, Chung YR. Effects of treadmill exercise-intensity on short-term memory in the rats born of the lipopolysaccharide-exposed maternal rats. J Exerc Rehabil 2015;11:296-302.

Kim SE, Ko IG, Shin MS, Kim CJ, Jin BK, Hong HP, Jee YS. Treadmill exercise and wheel exercise enhance expressions of neutrophic factors in the hippocampus of lipopolysaccharide-injected rats. Neurosci Lett 2013;538:54-59.

Lee TH, Kim K, Shin MS, Kim CJ, Lim BV. Treadmill exercise alleviates chronic mild stress-induced depression in rats. J Exerc Rehabil 


\section{5;11:303-310.}

Lindqvist A, Mohapel P, Bouter B, Frielingsdorf H, Pizzo D, Brundin P, Erlanson-Albertsson C. High-fat diet impairs hippocampal neurogenesis in male rats. Eur J Neurol 2006;13:1385-1388.

Molteni R, Barnard RJ, Ying Z, Roberts CK, Gómez-Pinilla F. A high-fat, refined sugar diet reduces hippocampal brain-derived neurotrophic factor, neuronal plasticity, and learning. Neuroscience 2002;112:803814.

Ming GL, Song H. Adult neurogenesis in the mammalian central nervous system. Annu Rev Neurosci 2005;28:223-250.

Navarro A, Gomez C, López-Cepero JM, Boveris A. Beneficial effects of moderate exercise on mice aging: survival, behavior, oxidative stress, and mitochondrial electron transfer. Am J Physiol Regul Integr Comp Physiol 2004;286:R505-511.

Park HR, Park M, Choi J, Park KY, Chung HY, Lee J. A high-fat diet impairs neurogenesis: involvement of lipid peroxidation and brain-derived neurotrophic factor. Neurosci Lett 2010;482:235-239.

Rolland Y, Pillard F, Klapouszczak A, Reynish E, Thomas D, Andrieu S, Rivière D, Vellas B. Exercise program for nursing home residents with Alzheimer's disease: a 1-year randomized, controlled trial. J Am Geriatr Soc 2007;55:158-165.

Sairanen M, Lucas G, Ernfors P, Castrén M, Castrén E. Brain-derived neurotrophic factor and antidepressant drugs have different but coordinated effects on neuronal turnover, proliferation, and survival in the adult dentate gyrus. J Neurosci 2005;25:1089-1094.
Simon D, Nascimento RI, Filho EM, Bencke J, Regner A. Plasma brain-derived neurotrophic factor levels after severe traumatic brain injury. Brain Inj 2016;30:23-28.

Stranahan AM, Norman ED, Lee K, Cutler RG, Telljohann RS, Egan JM, Mattson MP. Diet-induced insulin resistance impairs hippocampal synaptic plasticity and cognition in middle-aged rats. Hippocampus 2008;18:1085-1088.

Valladolid-Acebes I, Stucchi P, Cano V, Fernández-Alfonso MS, Merino B, Gil-Ortega M, Fole A, Morales L, Ruiz-Gayo M, Del Olmo N. High-fat diets impair spatial learning in the radial-arm maze in mice. Neurobiol Learn Mem 2011;95:80-85.

von Bohlen und Halbach O. Immunohistological markers for proliferative events, gliogenesis, and neurogenesis within the adult hippocampus. Cell Tissue Res 2011;345:1-19.

Winocur G, Greenwood CE. Studies of the effects of high fat diets on cognitive function in a rat model. Neurobiol Aging 2005;26 Suppl 1:46-49.

Woo J, Shin KO, Park SY, Jang KS, Kang S. Effects of exercise and diet change on cognition function and synaptic plasticity in high fat diet induced obese rats. Lipids Health Dis 2013;12:144.

Yi SS, Hwang IK, Yoo KY, Park OK, Yu J, Yan B, Kim IY, Kim YN, Pai T, Song W, Lee IS, Won MH, Seong JK, Yoon YS. Effects of treadmill exercise on cell proliferation and differentiation in the subgranular zone of the dentate gyrus in a rat model of type II diabetes. Neurochem Res 2009;34:1039-1046. 